Raisa Zianiuk

Belarus Institute of History NAN

DOI: 10.15290/rtk.2021.20.06

iD $0000-0002-4743-3538$

\title{
The Evolution of the Role of Roman Catholic Monasteries in Belarus from the Nineteenth Century to the Beginning of the Twentieth Century
}

This article presents how the role of Roman Catholic monasteries evolved in Belarus from the nineteenth to the beginning of the twentieth centuries. It defines the traditional internal and external functions of the Catholic monastery and proceeds to convey how, due to Russian policies, Roman Catholic monasteries ceased to fulfill their traditional roles and took on new, unusual, and previously uncommon functions such as serving as prisons and boarding houses.

Key words: Roman Catholic Church, monasteries, Russian Empire, nineteenth century, role of monasteries.

Roman Catholic monasteries and convents were traditionally created to organize the communal life of members of a specific religious order or congregation. Over time, the monasteries served to provide housing for the members of the religious order and space for them to carry out a variety of professions. Generally speaking, the functions of the monastery could be divided into two categories: internal and external. Internal functions were subordinated to the monastery's main purpose: to organize the life of a number of monks in accordance with a religious order's statutes and constitutions. The monastery became a place of residence, prayer, contemplation, religious study, formation (for novices), and the daily rule of life for the religious who lived there. In this way, the monasteries played an organizational, educational, and preparatory role. Monasteries also had lesser (but not less important) 
History of the Church

functions such as keeping an archive (a collection of stored texts documenting the history and life of the monastery) and a monastic library. Depending on the order or congregation, elections of superior generals, provincials, priors, and other leaders in the order and province took place at monasteries. These internal roles were exclusive to the members of the religious orders or monastic communities; those outside had no influence on these functions.

The external roles that monasteries played depended on the religious order and the nature of its ministry, which were defined in the order's statutes and constitutions. For example, the monasteries of the Bonifraters and Brothers of St. Roch ran and owned hospitals, while the Jesuits and Piarist monasteries became educational centers. Their external roles also had a social dimension: for example, religious orders ran shelters for the poor and homeless (hospitals). Because the monasteries needed to support themselves financially, they took on an economic role. People outside of the monasteries, such as the founders, often had an influence on the functions of the monasteries.

After Belarusian-Lithuanian lands were annexed by and partitioned to the Russian Empire, the status of the Catholic Church changed dramatically. The Orthodox Church became the "dominant" and "ruling" religious body, ${ }^{1}$ while the Catholic Church was simply "tolerated" (терпимого). Political events-namely, the November and January Uprisings-significantly influenced the evolution of the monasteries' roles. According to popular opinion, Catholic clergy played an important part in these uprisings. Even modern historical accounts of the November Uprising refer to Roman Catholic monasteries as "rebel strongholds."

The role of the monasteries as places where religious gathered to elect their abbots and provincials was the first to be abolished. In November 1798, the Russian authorities issued "Regulations for Roman

1 С.В Миненко, “Российское законодательство по охране господствующей православной веры от прозелитизма иноверческих церквей (XVIII-XIX века)” in Юридическая наука и практика: вестник Нижегородской академии МВД России // Рэжым достуnа, accessed June 10, 2020, https://cyberleninka.ru/ article/n/rossiyskoe-zakonodatelstvo-po-ohrane-gospodstvuyuscheypravoslavnoy-very-ot-prozelitizma-inovercheskih-tserkvey-xviii-xix-veka/ viewer.

2 С.А. Лукьянов, "Удодов А.Г. К вопросу о государственно-правовом регулировании деятельности Римско-католической церкви в России," in Государственная служба и кадры, №2 (2018), accessed September 11, 2021, https://cyberleninka.ru/ article/n/k-voprosu-o-gosudarstvenno-pravovom-regulirovanii-deyatelnostirimsko-katolicheskoy-tserkvi-v-rossii. 
Catholic Churches and Monasteries within the Russian Empire."3 These regulations confirmed the right of Roman Catholic bishops to oversee monasteries and churches and to make visitations to monasteries within the Russian Empire. Religious were obligated to be obedient to diocesan authorities. The reform was carried out in relation to the decrees of the Council of Trent and papal orders. ${ }^{4}$ Along with the ordinances, the Highly Approved Senate Report was issued, which forbid religious to travel to their chapter sessions for religious History of the elections. ${ }^{5}$ Emperor Paul I temporarily restored this right to religious orders and monasteries in 1800 by signing a series of points entitled "On the Administration of Roman Catholic Clergy in Russia." ${ }^{6}$ According to these points, broad internal autonomy as well as the freedom to elect provincials was restored to religious orders. ${ }^{7}$ In this way, orders were able to return to the traditional organization of their elections, with the provincials as the heads of religious orders and the priors as the heads of the monasteries. With the decrees issued on November 19 and December 16, 1842, respectively, the position of provincials was abolished once again. The bishop was then granted authority over the religious who worked in his diocese, while one member of each chapter was chosen to govern the monks. In this way, in place of twelve provincials (which reflected the number of religious orders that survived during this period), six visitators (one per diocese) were introduced. ${ }^{8}$

The decree issued on December 18, 1842, endowed bishops with the right to appoint diocesan visitators ("deans of the monasteries") based on the regulations of 1798 , according to which all monasteries were place under the bishops' authority. The visitators had direct supervision over all of the monasteries within a diocese and were required to participate on consistories. In addition, they had to maintain contact with the abbots of the monasteries regarding all monastic matters. The monks of the same religious order who resided in different monasteries

3 “Регламент для церквей и монастырей Римско-Католического исповедания в Российской империи,” in ПСЗРИ, №18 734. - Т. 25. - С. 436-438.

Полное обрание законов Российской империи (ПСЗРИ), №18 734. - Т. 25. - С. 436-438.

ПСЗРИ, №18 733. - Т. 25. - С. 435-436.

ПСЗРИ, №19 684 - Т. 26. - С. $43-437$.

М.А. Попов, “Митрополит Станислав Богуш-Сестренцевич (1731-1826 гг.): роль в формировании правительственной политики по отношению к Римско-католической церкви на белорусских землях (конец XVIII - первая четверть XIX в.).” - С. 65. 
History of the Church

within the six diocese of the Russian Empire lost the traditional ties that they had with each other. ${ }^{9}$ In this way, the democratic elements characteristic of religious orders-namely, the election of provincials and priors as well as chapter meetings-were abolished. ${ }^{10}$

\section{The abolition of religious studies}

When studies intended to prepare candidates for the religious life were abolished, the traditional system of religious formation was likewise abolished. Instead of the novitiate and then studies, the order was reversed, and seminary studies came before the novitiate. As of December 11, 1844, it was decreed:

[I]n order for a candidate to make religious vows, it is irrefutably necessary that the vows be made freely and with conviction. This conviction should be based on experience and knowledge of the very social life that those who enter an order renounce and on the complete validity of the vows that they must make. And since religious have entered and asked to be dispensed from their vows, which they made-as they express, without having experience and without an inner calling-only because of their teachers' religious influence, the Emperor commands the following in order to protect the monks from such exceptions:

1. All religious who have not yet made their vows (vota solemnia) and are studying should enter diocesan seminaries to complete their studies.

2. Those who do not wish to enter the seminary should leave their monasteries. If, however, they wish to join the Order once again, they are required to ask for the government's permission as indicated by the law. 3. All monastic studies must cease. ${ }^{11}$

\section{Abolition of prerogatives}

Religious orders also could no longer determine how many religious lived in a given monastery. After the November Uprising, the Holy See ordered that those monasteries with only a few monks close. Pope Benedict XIV's papal bull of 1744 was the pretext for this cassation. In 1832, Emperor Nicholas I issued a decree that resulted in the liquidation of 199 monasteries. $^{12}$

\footnotetext{
9 M. Valančius, Namų užrašai, 188.

$10 \quad$ Ibid.

11 Ibid, 276.

12 Е.Н. Филатова, “Конфессиональная политика царского правительства в Беларуси 1772-1860 гг.” (Минск : Белорусская наука, 2006). - С. 82.
} 
In the list issued on August 6, 1832, which was based on proposals made by the Minister of the Interior of the Roman Catholic Ecclesiastical College, Article Number 1547 states:

His Imperial Majesty commands:

1. Based on the decrees of 1798 , diocesan bishops are granted full authority over monasteries to better organize religious practice in monasteries and to establish strict supervision of religious clergy...

2. All monasteries that are not full and lack the means necessary to maintain order and piety among the religious must be abolished. The names of these monasteries will be placed on a special list. Only the monasteries that take in monks from the abolished monasteries will be excluded from this general rule.

3. Monasteries located between Greek-Russian and Uniate villages and/ or whose monks are of an alien faith and are not needed to fulfill any spiritual needs also must be liquidated. ${ }^{13}$

On August 12, 1832, a circular from the Office of the Governor of Vilnius, acting Governor of Grodno and Białystok, was sent to Governor Murawiów of Grodno, stating, among other things: "According to canon law, every monastery should have at least 10 monks. It has been observed for some time that Roman Catholic monasteries in western governorates have fewer than 10 monks. In a papal bull issued in 1744, Benedict VIII declared 'that many monasteries in Polish provinces have reached [a state of] extreme poverty and are barely able to support two or three monks,' and he ordered several monasteries to be merged into into one...."14 This was the explanation for the cassation of the monasteries.

13 " 1 . On the basis of the resolutions of 1798 , diocesan bishops are granted complete authority over the monasteries to better organize the monasteries within the deanery and to establish the closest supervision of the monastic clergy possible. 2. Immediately abolish and liquidate all monasteries that do not have the means necessary to maintain order within themselves and the in the deanery, designating them by name in a special document. Only those monasteries that provide housing to monks to a greater or lesser degree are excluded from this general rule. 3. Also to abolish monasteries that are in the middle of Greek-Russian and Uniate villages and whose monks serve in parishes using alien rites that are not useful in fulfilling any spiritual need." In Нацыянальна гістарычны архіў Беларусі ў г. Гродна (НГАБ Гродна) Ф.1. Воп.27. Спр. 233, k. 7-10.

14 "According to canon law, every monastery must consist of at least 10 monastics. In the Roman Catholic monasteries of the Western provinces a lack of this many monastics has, for the most part, already been observed for a long time. Back in 1744, Benedict VIII, declared via a bull 'that many monasteries in the Polish province have reached a state of extreme poverty and are barely able to support two or three monks" and ordered that several monasteries be merged into one..." in НГАБ Гродна Ф.1. Воп. 27. Спр. 233, k. 1-6 адв. 
History of the Church

Subsequent decrees mandated a number of restrictive measures. The decree issued on July 30, 1842 ordered all Roman Catholic monasteries within the Russian Empire be divided into two categories: those to be preserved and those to be abolished (the latter were to be liquidated gradually. The orders that resided in monasteries that were to be preserved were not permitted to have a novitiate, which led to their gradual self-demise. In the Russian Empire a quota of 50 (36 male and 14 female) monasteries was set. In addition to categorizing the monasteries, the aforementioned decree also stipulated that the classes within monasteries should be divided so that the proper number of residents could fill it. For example, a male first-class monastery, should have no less than 22 people; a second-class should have no less than 13 people each, and a third-class should have no less than 13 people. In female monasteries, a first-class monastery should have no less than 19 nuns; second-class should have no less than 16 nuns, and third-class should have no less than 11 nuns. ${ }^{15}$

If a vacancy arose in a preserved monastery, then a monk from the same order but another monastery was transferred to fill the vacancy. As long as a monastery that was designated to be abolished had resident members, new members were forbidden to enter. ${ }^{16}$ Individuals who entered religious orders after 1829 or who worked with parish priests without the Minister of the Interior's approval did not receive financial support from the treasury. ${ }^{17}$ Consequently, the number of monasteries steadily decreased. In 1864, there were 16 male monasteries designated to be preserved and 5 male monasteries designated to be abolished as well as 12 female monasteries designated to be preserved and 4 female monasteries designated to be abolished ${ }^{18}$ in the 6 western provinces. ${ }^{19}$ By 1905, this number had fallen to only 3 monasteries in Belarus: the Franciscans and Brigittines in Grodno and the Bernardines in Słonimiu.

\section{Abolition of economic freedoms}

The Russian authorities made another series of decisions to prevent Catholic orders and congregations and their monasteries from performing their economic roles. On December 25, 1841, Emperor

15 Католическая Церковь накануне революиии 1917 г. Сборник документов. - С. 45.

16 M. Valančius, M. Namų užrašai, 140.

$17 \quad$ Ibid.

18 В.В. Яноўская, Хрысиіянская изарква ў Беларусі ў 1863-1914 г2 (Мінск : БДУ, 2002$), 44$.

19 Wileńska, Witebska, Grodzieńska, Mińska, Mohylewska, Kowieńska. 
Nicholas I issued a decree that changed how monasteries could make a living. By virtue of this decree, all immovable and settled monastic properties were to be handed over to and placed at the disposal of the Ministry of State Property. ${ }^{20}$

On January 1, 1842, a second similar decree was issued. This decree divided monasteries based on whether they were designated to be preserved or abolished and class, and then allocated a designated subsistence to each. First-class monasteries received 3,185 rubles annually, second-class monasteries obtained 2,155 rubles, and thirdclass collected 1,455 rubles. Financing for monasteries designated to be abolished depended on the number of inhabitants; 40 rubles were allocated to each person annually. ${ }^{21}$ On January 15, 1842, all capital belonging to the Catholic Church, including monastic capital and capital designated to maintain educational facilities were confiscated and handed over to the treasury. ${ }^{22}$

\section{Abolition of educational and social roles}

The Russian Empire began to place limitations on the educational role of monasteries beginning in 1820 when it banned the Jesuits from the empire. Other religious orders, however, were still able to run both primary (parochial) and secondary (district and middle) schools. Changes in the borders of academic districts that took effect during the 1820 s played a role in the ban on running educational institutions that was placed on some religious orders (e.g., the Dominicans at Orsha, who had taken over after the Jesuits, were banned). The cassation of monasteries that took place in 1832 naturally caused the educational institutions associated with them to close. In the late $1830 \mathrm{~s}$, all male religious orders were forbidden from educating the laity, and by the mid-1840s, the same occurred to female religious orders. ${ }^{23}$

\section{Abolition of monastic archives and libraries}

Needless to say, the mass wave of cassations negatively affected monastic archives. During the dissolution of the monasteries, documents that were stored in the archives were divided into different categories,

\footnotetext{
20 Valančius, M. Namų užrašai, 142.

$21 \quad$ Ibid, 138.

22 Ibid, 146.

23 Р.У.Зянюк, Навучальныя ўстановы рымска-каталіикай царквы ў Беларусі (1772 - 1914 г2.) (Мінск 2017).
}

History of the Church 
History of the Church

depending on the content: economic-financial and other. The Russian authorities were interested only in documents from the first category, since they provided proof of the monasteries financial and economic supply networks. The Russian authorities took these documents to the Office of the Treasury to ensure that the empire could take over all of the property and confirm its rights to it. For example, during the cassation of the monastery that belong to the Bernardines in Mścisław in September 1832, the monastery archive was described as a separate item in the inventory of the estate and monastic buildings. A special delegate of the State Treasury had to deliver such documents. ${ }^{24}$ Documents made from hazelnuts, which recorded who owned the land, settlements, peasants, and tertiaries, were of particular interest because the moment that the monastery was liquidated, everything was taken to the treasury and would become the basis for auxiliary capital for Catholic clergy. Such documents were to be handed over to a special delegate of the State Treasury.

In some cases, the second category of documents was transferred to diocesan archives or transported to another monastery of the same religious order. Sometimes these documents were also handed over to secular authorities. In other instances, the documents were not moved at all and were destroyed (e.g. due to poor storage conditions) over time. ${ }^{25}$

When the institutions that existed at the monasteries were liquidated, their documents were transferred to the appropriate department. ${ }^{26}$ When the religious communities were cassated, most often their documents were destroyed. For example, on April 20, 1868, the General-Governor of Vilnius, Kaunas, Minsk, and Grodno issued an

24 Нацыянальны гістарычны архіў Беларусі (НГАБ). Ф.2001. Воп. 1.Спр. 137.Р.У. “Зянюк, Касацыя рымска-каталіцкіх кляштараў у Мсціславе ў XIX ст.,” Веснік Магілёўскага дзяржаўнага ўніверсітэта імя Куляшова. - Серыя А. Гуманітарныя навукі 57, № 1 (2021): 35-41. Р.В. Зенюк, “Организация, деятельность и судьбы архивов римскокатолических монастырей Беларуси в конце XVIII - XIX веке,” Вестник Брянского государственного университета 45№3 (2020): 62-71.

Р.У. Зянюк, “Касацыя рымска-каталіцкіх кляштараў у Мсціславе ў ХІХ ст.,” Веснік Магілёускага дзяржаўнага ўніверсітэта імя Куляшова. - Серыя А. Гуманітарныя навукі 57, № 1 (2021): 35-41, Р.В.Зенюк, “Организация, деятельность и судьбы архивов римско-католических монастырей Беларуси в конце XVIII - XIX веке,” Вестник Брянского государственного университета 45, №3 (2020): 62-71. 
order to close all parish fraternities. All of the fraternities' symbolic signage and books had to be burned. ${ }^{27}$

The abolition of these monastic roles was the result the Russian authorities' policies, which were intended to preserve and strengthen the position of the Orthodox Church in Belarusian-Lithuanian lands. These policies were meant, for example, to restrict and prohibit education and ban missionary activity, which could at least indirectly affect the Catholic Church's influence on the people's desire to convert to History of the Catholicism. The Russian authorities did not fully understand the essence and peculiarities of the relationship between religious orders and their monasteries; therefore, they often thought of the monastery as independent when performing different tasks. The incorporation of Belarusian-Lithuanian lands into the Russian Empire prompted the authorities to apply their Orthodox understanding of monastic life to the Catholic one. In this way, the manner in which monasteries were organized and not the way of life of the religious orders that inhabited them became the focus. As a result, Catholic monasteries also took over tasks and functions that were characteristic of Orthodox monasteries and not traditional for Roman Catholic religious.

The first function that the secular authorities imposed on Roman Catholic monasteries was to make them serve as penitentiaries. ${ }^{28}$ In this regard, Orthodox monasteries served as a model for the Catholic monasteries. In Russia, it was common to send people who had socialization issues or other problems with state or church law to monasteries.

The transformation of Roman Catholic monasteries into penitentiaries came about solely through the actions of the civil authorities: They were the ones who chose to "place [offenders] in a monastery" as a means of punishment. At the same time, they did not choose specific monasteries. Instead, verdicts simply noted: "one of the distant monasteries,"29 "Belarusian monasteries," etc. In turn, the clerical authorities (e.g., consistory) selected the monastery. The provincials or priors of monasteries were required to carry out the sentences in the monasteries under their governance.

27 Р.У.Зянюк, “Барацьба з рымска-каталіцкімі брацтвамі як форма абмежавання ўпляву касцёла ў другой палове XIX стт.," Паустанне 1863 - 1864 г2. у Польшчь, Беларусі, Літве і Украіне: гісторыя і памяць : зб. навук. арт," arr. В.В. Яноуская, А.У. Унучак, and А.Э. Фірыновіч, ed. А.А. Каваленя et. al (Мінск : Бел. навука, 2014), 287. facility. 
History of the Church

The role of monasteries serving as penitentiaries became particularly important after the November Uprising. After the uprising was suppressed, those from the Kingdom of Poland and western governorates who were accused of participating in it or had "connections with the insurgents" and were convicted as "rebel sympathizers" (сочувствующие мятежникам) served their sentences in Belarusian monasteries. One such individual, Fr. Kamasiński, from the Kingdom of Poland was sentenced to 10 years imprisonment in a monastery for being "connected with insurgents." ${ }^{30} \mathrm{He}$ was placed first in the Dominican monastery in Polotsk. In the spring of 1835 , he was transferred to the monastery of the Canons Regular of the Lateran in Bychów where he continued his sentence. ${ }^{31}$

According to the confirmation of the Governor-General of Vilnius, Grodno, Minsk, and Białystok in 1834, Fr. Anatoly Szymborski, the parish priest of the church in Eziorosy, was among the "people of various ranks convicted of being complicit and liaising with the emissary Szymański from France." He served his sentence in the Bernardine monastery in Mogilev. The notes indicate that he had to be placed "under strict supervision." 32 Fr. Szymborski was transferred to the Dominican monastery in Agłona and placed "under the strict supervision of both the clergy and the police." ${ }^{33}$ He was then moved because of "illegal activities" ${ }^{34}$ such as unauthorized entry into the city, as reported by the local police. According to the report, "instead of remaining permanently in the monastery, he freely moves about everywhere and even teaches students publicly in Mariawitek and in the home of the former commander Wyłoskow and of councilor Radkewicz." ${ }^{35}$ In addition, the prior of the monastery complained about Fr. Szyborski's behavior, adding that "he has neither honor nor a conscience," 36 and "due to his restless nature, Szymborski cannot be tolerated in the life of the monastic community." ${ }^{37}$

The Commission of Investigation of Political Criminals, Fr. Feliks Wyszyński, from the Diocese of Vilnius and Fr. Józef Reniger from

\footnotetext{
30 НГАБ. Ф.1781. Воп. 2. Спр.546, k. 1.

31 НГАБ. Ф. 1781. Воп. 2. Спр. 546, k. 4.

32 НГАБ. Ф. 1781. Воп. 2. Спр. 555, k. 2-2 адв.

33 НГАБ. Ф. 1781. Воп. 2. Спр. 555, k. 2 адв.

34 НГАБ. Ф. 1781. Воп. 2. Спр. 555, k. 8

35 НГАБ. Ф. 1781. Воп. 2. Спр. 555, k. 10-10 адв.

36 НГАБ. Ф. 1781. Воп. 2. Спр. 555, k. 8 адв.

37 НГАБ. Ф. 1781. Воп. 2. Спр. 555, k. 10 адв.
} 
Żyrmuny to the Bernardine monastery in Mogilev-the former in $1847^{38}$ and the latter in 1848 - for "a punishable and dangerous way of thinking." 39 Over time, both priest were also permitted to go into the city regularly. ${ }^{40}$

By the beginning of 1844, the Roman Catholic Ecclesiastical College requested that the Minister of the Interior pay a certain amount to support Catholic priests who, by order of the civil authorities, were being detained in monasteries as punishment. In a letter dated FebruHistory of the ary 8,1844 , the minister replied to this appeal, stating that, by virtue of the highest decree issued on October 21, 1843, he agreed that 4 silver rubles from the auxiliary capital for clergy would be issued monthly to every priest detained by order of the civil authorities and placed in a monastery until his case had been reviewed. He entrusted the Roman Catholic Ecclesiastical College with this duty." 41

Most often, "political" priests were sent to following monasteries: the Bernardines in Mogilev, the Franciscans in Grodno, and the Dominicans in Agłona. The authorities' execution of such sentences was complicated by their own repression of the Catholic Church: after the first wave of closures and liquidation of the monasteries in 1832, the authorities halved the places to which they could exile clergy in Belarus. Of the monasteries that remained, those that could serve as prisons were limited by the number of monks residing in them and the living conditions.

As of May 1, 1851, 5 priests had been sentenced to imprisonment in 3 monasteries in the Mogilev and Vitebsk governorates. Two aforementioned priests were sentenced to imprisonment in the second-class monastery of the Bernardines in Mogilev, which was designated to be preserved. The Commission of Investigation of Political Criminals sentenced Fr. Feliks Wyszyński to incarceration beginning on March 22,1848 . He was to receive 16 rubles per month for room and board. The high commander of the army sentenced Fr. Józef Reniger to imprisonment in the Bernardine monastery beginning in December 1848. Like Fr. Wyszyński, Fr. Reniger received 16 rubles per month in accordance with Metropolitan Dmochowski's proposal. One priest, Fr. Adam Szbuniewicz, was imprisoned in the Dominican monastery in Agłona beginning on March 2, 1851, while two priests were imprisoned

НГАБ Ф. 1781. Воп. 2. Спр. 3150, k. 1-2.

НГАБ Ф. 1781. Воп. 2. Спр. 3150, k. 9.

НГАБ Ф. 1781. Воп. 2. Спр. 3150, k. 24 адв.

M. Valančius, Namu užrašai, 270. 
History of the Church

in the preserved Dominican monastery in Zabiały: Fr. Jan Polińsky in 1836, and Fr. Kleogas Katkiewicz in $1850 .{ }^{42}$

The next wave of monastic imprisonments began as a result of the "political" sentences that were issued for those who participated in the January Uprising, which had been suppressed. In 1870, a monk from the Carmelite monastery in Vilnius, Saturnin Budin, was accused of "receiving a circular with criminal content that was sent by Fr. Stanisław Piotrowicz on March 25; of not showing it immediately to his superiors; and of being permitted to show it to others after keeping it for a long time." For this offense, "by order of the Head of State, he was sent to the Franciscan monastery in Grodno" ${ }^{43}$ to live "under the priory's surveillance." The police escorted such individuals to the monasteries. The governorate authorities had to inform both the local commandant via a special report and the prior when these individuals were brought and admitted to the monasteries. ${ }^{44}$ Such sentences usually lasted one year, as was the case of Saturnin Budin, who was sent to Grodno on April 5, 1870 and was released in May 1871 by the order of the Governor-General of Minsk, Kaunas, and Grodno. The monastery guard, the Dean of Grodno, and the Governor of Grodno were informed about this in writing. After serving his sentence, Fr. Budin had to return to Vilnius. ${ }^{45}$

Monasteries served as penitentiaries until the beginning of the twentieth century. ${ }^{46}$ Even those who had committed non-political crimes were imprisoned in them. Such restrictive and corrective measures were called penance (эпитимия). Most often, those who were incarcerated were alcoholics and mentally ill clergy. Fr. Klemens Mikucki was sent to the Dominican monastery in Zabiały for alcoholism. ${ }^{47}$ Fr. Olszewski was also sent to the Franciscan monastery in Vilnius for alcoholism in the autumn of $1837 .{ }^{48}$ In 1853 , the consistory decided to send the pastor of the parish in Faszczów, Fr. Misiewicz, to the Bernardine monastery in Mogilev for drunkenness. ${ }^{49}$ In the autumn of

\footnotetext{
42 НГАБ. Ф. 1781. Воп. 2. Спр. 3150, k. 38-39.

43 НГАБ (Гродна). Ф. 1. Воп. 6. Спр. 2049, k. 1-1 адв.

44 НГАБ (Гродна). Ф. 1. Воп. 6. Спр. 2049, k. 4,5.

45 НГАБ (Гродна). Ф. 1. Воп. 6. Спр. 2049, 1870 г., k. 6, 8, 9.

46 НГАБ (Гродна). Ф. 1. Воп. 18. Спр. 809, НГАБ (Гродна). Ф. 1. Воп. 18. Спр. 808, НГАБ (Гродна). Ф. 1. Воп. 18. Спр. 807.

47 НГАБ. Ф. 1781. Воп. 2. Спр. 2292.

48 НГАБ. Ф. 1781. Воп. 2. Спр. 2044.

49 НГАБ. Ф. 1781. Воп. 2. Спр. 3912, k. 5-6.
} 
1836, the priest of the parish in Leszczyłów, Fr. Jan Wojdak, was sent to the monastery in Zabiały for one month of penance. According to the prior of the monastery, Fr. Donat Olseyko, Fr. Wojdak was duly humble throughout his "month-long retreat." 50

The length of the sentences varied: some lasted 10 years, while others lasted one year or one month. The length of other sentences was undetermined ("until rehabilitated"). Catholic monasteries did not adapt well to serving as penitentiaries: first, because they did not have a tradition of forcefully confining people, and second, because they did not have the means (including financial) to do so, especially after 1842. As a result, the monasteries' role as a penitentiary was completely formal. Priests who were sent to monasteries had virtually no restrictions other than serving as actual clergy: for example, they were banned from preaching or hearing confessions. They had the ability to leave the monastery every day; therefore, their imprisonment was not "corrective" as such. For example, according to the prior of the Dominican monastery in Zabiały, Fr. Klemens Mikucki, who had been sent there in 1841 for drunkenness, went to the local inn every day and even spent the night there on occasion. The lack of control allowed Fr. Mikucki to escape from the monastery twice. ${ }^{51}$

"Prisoners" were transferred from one monastery to another, which made it difficult for monasteries to fulfill their penitentiary role. The aforementioned Fr. Klemens Mikucki, who was imprisoned in the Dominican monastery in Zabiały for 3 years (1841-1844), was transferred to the Bernardine monastery in Mogilev in 1844. However, soon after, he was transferred elsewhere because the monks complained that they were unable to keep Mikucki in the monastery due to his mental illness and suicidal tendencies and requested that he be moved to another "institution that is pleasing to God." When he returned to the Dominican monastery "cured" one year later, he soon began to behave obscenely again; he drank, left the monastery without permission, and roamed the city drunk. ${ }^{52}$

Sometimes and for different reasons diocesan clergy expressed a desire to live temporarily in monasteries. In principle, this phenomenon was normal; priors or religious leaders would decide to permit a diocesan priest to live at a monastery if he requested. During the second half of the nineteenth century, however, the order of command for making such decisions changed. Therefore, when Fr. Ferdynand

\footnotetext{
50 НГАБ. Ф. 1781. Воп. 2. Спр. 620, k. 6-6 v.

51 НГАБ. Ф. 1781. Воп. 2. Спр. 2292.

52 НГАБ. Ф. 1781. Воп. 2. Спр. 2292, k. 31, 34 v. 35, 60-62.
} 
History of the Church

Sęczykowski wanted to the live in the Franciscan monastery in Grodno in the summer of 1882, he sent a request to the Governor-General of Vilnius, Kaunas, and Grodno, asking to be released from his position due to a serious decline in his health and requesting to live in a monastery. It was the governorate authorities that dealt with this problem. After consulting with the Minister of the Interior, the Office of the Governor-General sent an inquiry to the Governor of Grodno about transferring Sęczykowski. ${ }^{53}$ The Governor of Grodno consulted only with the Commander of Grodno, who decided that there were "no impediments" to this. ${ }^{54}$ Then the situation developed through notification. The Minister of the Interior sent an order to the administrator of the Diocese of Vilnius, Msgr. Żylinski, who then informed the custodian of the Grodno monastery in Steckiewicz. In a letter dated July 31, 1882, Msgr. Żyliński informed the Governor of Grodno about the orders that had been issued and noted that Fr. Sęczykowski had been granted a pension of 500 rubles per year and that, due to the small number of religious living in the monastery in Grodno, the "custodian of the Franciscan monastery in Grodno should be ordered to prepare a room in the monastery." 55

However, solving such issues from the top-down did not take into consideration the aspects of the local life both of a small religious community and the broader surrounding community. For example, allowing a famous representative of the polonized church and proponent of its russification to reside in a monastery caused an uproar and was met with hostility, as the head of the Grodno provincial police secretly reported to the voivode in December 1882:

Meanwhile, Sęczykowski's introduction and use of Russian in this devotion and another Catholic prayer book in the province of Minsk provoked fanatic priests, who did not allow for the possibility that Polonism could be separate from Catholicism, against him. Many priests do not even consider it necessary to hide their anger from Sęczykowski. Thus, the abbot of the Franciscan monastery, Father Steckiewicz, completely ignored Sęczykowski when he was placed in that monastery, refusing even to accept from him the candlesticks that he had donated to the altar and the church. As I recall, on December 7, the Franciscan monk Fr. Lyavnich (?) did not agree to hear Fr. Sęczykowski's confession and told him that he had been excommunicated from the church. I then contacted the dean of the church in Grodno Garnago, the Archdeacon of Bialystok, Fr. Jan Małyszewicz, who explained that Father Lavnichy,

\footnotetext{
53 НГАБ (Гродна). Ф. 1. Воп. 8. Спр. 811, k. 1.

НГАБ (Гродна). Ф. 1. Воп. 8. Спр. 811, k. 3. 
who is 74 years of age, often suffers from rushes of blood to the head and dizziness, and therefore does not remember whether Fr. Sęczykowski approached him and asked him to hear his confession and whether he told Fr. Sęczykowski that he was excommunicated. Not rejecting the possibility that he could have lied about the above occurrence, and considering it incompatible with the dignity of the authorities to permit such a person whose loyalty to the government is unquestionable to be to be treated in such a manner, I attribute the antics of Lyavnich to the bad influence of Abbot Steckiewicz, who, moreover, according to the rumors that have repeatedly reached me, taking advantage of the isolated location of the monastery on the outskirts of the city of Cemn, he often travels to the countryside without permission, and the close proximity of the Suwałki Voivodeship makes it possible for him to indiscriminately and excessively hear the confessions of the inhabitants of that area, which ultimately may have negative consequences. ${ }^{56}$

This situation provoked a wave of proceedings that involved the governor, the director of the Department of Foreign Cults, and the monastery's inhabitants. Clearly, the governor was aware of Steckiewicz's character, which he wrote about in his letters. As a result of the trial, the monastery custodian was warned that it was inadmissible to beat Sęczykowski. The governor informed the director of the department of the outcome: "There is no evidence to suggest that Fr. Steckiewicz is politically or morally unreliable, and keeping in mind that Fr. Steckiewicz has a somewhat restless character and, therefore, can get carried away by his emotions, which evokes the hatred of those around him, he does not manifest this in a concrete way. I limited myself, therefore, to convincing Fr. Steckiewicz by warning him that [if I receive] further complaints [I will] remove him from his position as guardian."

Occasionally, the Russian authorities used the monasteries as penitentiaries for laypeople. For example, convicted minors served their sentences there in $1834 .{ }^{57}$ This, however, did not become a permanent practice.

\section{Criminal psychiatric ward}

The first recorded abuses took place in Grodno in March 1836. Without the prioress of the Bernardine monastery Dominika Wasilewska's consent and even against her expressed opposition, the policeman Baiczewski placed three mentally ill women in her monastery. ${ }^{58}$ The

\footnotetext{
56 НГАБ (Гродна). Ф. 1. Воп. 8. Спр. 811, k. 12-13 v.

57 НГАБ (Гродна). Ф. 1. Воп. 19. Спр. 822.

58 НГАБ (Гродна). Ф. 1. Воп. 19. Спр. 1222.
}

History of the Church 
History of the Church

bailiffs and the chief of police sarcastically claimed that they could not find any other rooms with bars on the windows that would available for the Bernardines. ${ }^{59}$

In 1867, the noblewoman Bronisława Wieczerkowska was ordered to be placed in the Cistercian monastery in Kimbarw "on suspicion of associating with insurgents." ${ }^{60}$ At first, she was exiled to the city of Chembary in the Penza Governorate. With time, Mrs. Wieczorkowska exhibited mental problems, and the governors of Penza and Minsk as well as the minister of the interior decided to send her to the Cistercian monastery in Kimbarówka. Bronisława arrived to Kimbarówka on July 18, 1867. However, by 1871 her mental health had worsened (she had phobia of being poisoned in the monastery). As a result, the authorities decided to transfer her to the Dominican monastery in Nieśwież. At that time, however, the only Dominican monastery there was male. ${ }^{61}$

\section{Residences for elderly and sick priests}

As the number of monasteries in the Russian Empire decreased, so too did the hospitals associated with them. The authorities, however, decided to take advantage of this situation by turning old monasteries into homes for elderly and sick priests. In a decree issued on November 3, 1843 under the pretext of caring for elderly and sick clergy, the Emperor ordered that regular monasteries be designated as housing for elderly and sick clergy. In addition, disabled priests were to receive an annual salary of 50 to 100 rubles, according to their merits. For this purpose, certain sums were taken from the funds for Roman Catholic clergy and given to the bishops based on the number of parishes in a diocese. And so, the Diocese of Mogilev was given 1450 rubles, the Diocese of Minsk was granted 1100 rubles, and the Diocese of Vilnius was allotted 450 rubles. The bishops of every diocese had to send an account to the Roman Catholic Ecclesiastical College detailing how the money was spent.

One of the remaining monasteries in the Archdiocese of Mogilevthe Dominican monastery in Czaszniki-was chosen for the exclusive purpose of housing priests from the archdiocese. The housing was financed from the auxiliary capital for the clergy, which was created after the monasteries were closed and liquidated and their property

59 НГАБ (Гродна). Ф. 1. Воп. 19. Спр. 1222.

60 Российский государственный исторический архив (РГИА). Ф. 821. Оп. 1. Д. 1186.

61 РГИА. Ф. 821 . Оп. 1. Д. 1186, k. 1, 5, 7-7v. 
was consolidated into the treasury. ${ }^{62}$ However, according to the registered complaints of the monastery prior, Fr. Wincenty Spodoba, these payments ceased or were delayed for a significant length of time during the first few years. This delay was due to the fact that the dioceses needed to give a complete account of the funds received both to the clerical and secular authorities. ${ }^{63}$

The bishops tried to oppose the transformation of monasteries into homes for elderly priests and correctional facilities. On December History of the 27, 1861, Bishop of Vilnius Adam Stanisław Krasiński sent a letter to Metropolitan Żyliński asking him to pass it on to the emperor. In the letter, Bishop Krasiński described the situation of the Roman Catholic Church in his own diocese. In general, the diocese was constantly deteriorating both in the number of clergy, which resulted in a lack of men to serve in parishes, and facilities. In this regard, the bishop proposed that a series of measures be implemented to help strengthen the Church's position. Point 12 of the measure proposes that, "based on the decree of 1832, a sum from auxiliary capital be released for the establishment of an institution for elderly priests and those suffering from incurable diseases," and in point 13 he suggests that "the government build a house for criminal priests." ${ }_{44}$

\section{Boarding houses}

Due to the policies that the Russian authorities implemented, Roman Catholic monasteries in Belarus ceased to be religiously affiliated. The Russian authorities turned the monasteries into boarding houses that were run by members of different religious orders who were sent from liquidated monasteries. After the Dominican monastery in Nowogródek was closed for not being "politically transparent" in 1864 , some of the nuns were transferred to the Brigittine monastery in Grodno while others (9 nuns) were moved to the Benedictine monastery in Minsk. On September 2, 1868, ${ }^{65}$ Mariavites from the convent in Połock (Katarzyna Michałowska, Anastazja Pogodicka, Anna Łyko, Sołomea Gasperska, Florentyna Kiselewna, Rozalia Weryho, Agnieszka Balewiczóna, Klara Kruszewska, Franciszka Szymakowska, and Paulina Wołkowiczówna) ${ }^{66}$ were sent to the Bernardine convent

НГАБ. Ф. 1781. Воп. 2. Спр. 1911, without card numeration.

63 НГАБ. Ф. 1781. Воп. 2. Спр. 1911, without card numeration.

64 Літоўскі дзяржаўны гістарычны архіў (LVIA). Ф. 694. Воп. 1, Спр. 2162. k. 2, 2v., 42.

65 НГАБ (Гродна). Ф. 1. Воп. 6. Спр. 1661, k. 4.

66 НГАБ (Гродна). Ф. 1. Воп. 6. Спр. 1661, k. 6.
} 
History of the Church

in Słonim. The following were transferred to the Benedictine convent in Vilnius: 14 Mariavites in 1864, 2 Bernardines in January 1865, and 17 Carmelites in February $1865 .^{67}$

A similar situation occurred in 1867 in the Dominican convent in Nieśwież where 16 Dominicans, 9 Bernardines, 9 Benedictines, 2 Cistercians, and 2 Franciscans lived together. ${ }^{68}$ Both diocesan clergy and religious from different orders were sent to this monastery. Records from December 1885 indicate that nuns from various Bernardine convents (Grodno, Kroże, Vilnius) and Mariavite convent in Połock lived together in the Bernardine monastery in Słonim. ${ }^{69}$

In Grodno, boarding houses were divided into male and female- the female Brigittines and the male Franciscans. Members from almost all of the religious orders in Belarus and Lithuania were living in the Franciscan monastery in Grodno in the 1860s. From 1864-1865, Bernardines from the monastery in Słonim (Klefald Chylkiewicz and Filip Tarasiewicz), Marians from the monastery in Rasnia (Piotr Kryński, Joachim Piotrowski, and Karol Osmulski), the Piarists (Stanisław Jakukiewicz and Tomasz Siemienowicz), the Dominicans from the monastery in Poławeń (Dominik Polijan, Karol Frąckiewicz, and M. Jurewicz), and a Bonifraters from the monastery in Vilnius (Jan Skalski) were transferred there. ${ }^{70}$

In 1980, the Brigittines Eleanora Skrzenewska (71 years old), Antonina Żakiewich (72), Katarzyna Sarasiek (75), Juliana Strzyczeska (70); the Dominicans Teresa Korsak (84), Katarzyna Garkowicz (67); the Benedictines Sofia Odyniec (71), Scholastyka Chodasiewicz (44), and Katarzyna Cwirko (76) lived in the Bridgittine convent in Grodno. The government allocated a certain amount of money to support every person in each monastery, depending on the class of the monastery to which the person was transferred. So, the Grodno monastery received 40 rubles per year for each of the Dominican nuns transferred to Grodno. The Grodno Franciscan monastery received the same amount for every monk who was transferred there. Long delays in payment to support those transferred from other monasteries were a regular occurrence. Because life in common among so many different religious orders was complex, religious often requested to be transferred to a monastery that was run by "their own" order.

\footnotetext{
67 А.И.Ганчар, Римско-католическая иерковьв Беларуси (вт.пол. 19-нач. 20 вв.) (Гродно: Исторический очерк, 2010), 112.

68 НГАБ. Ф. 937. Воп. 6. Спр. 107.

69 НГАБ (Гродна). Ф. 1. Воп. 8. Спр. 1352., k. 16

70 НГАБ (Гродна). Ф. 1. Воп. 6. 1661, k. 11-12.
} 
Because of the Russian government's policies from the nineteenth century to the beginning of the twentieth century, many Roman Catholic monasteries ceased to function as they traditionally had as educational, economic, medical, and charitable centers. Instead, they took over roles that were traditional to Orthodox monasteries: prisons and correctional facilities. $\mathrm{n}$ addition, these same Roman Catholic monasteries also lost their religious identity as the members of various different religious orders and congregations were forced to live together under the same monastic roof.

\section{Bibliography}

1. Dołbiłow, M. Russkij kraj, czużaja wiera: etnokonfessionalnaja politika imperii w Litwie i Bietorussii pri Aleksandre I. Moskwa: 2010. (Долбилов, М. Русский край, чужая вера: этноконфессиональная политика империи в Литве и Белоруссии при Александре I. Москва: 2010).

2. Fiłatowa, E. N. Konfessuonalnaja politika carskogo prawitelstwa $w$ Biełarusi 1772-1860 gg. Minsk: 2006. (Филатова, Е.Н. Конфессиональная политика иарского правительства в Беларуси 1772-1860 г2. - Минск: 2006).

3. Ganczar, A. I. Rimsko-katoliczeskaja cerkow w Biełarusi (wt.pot. XIX - nacz. XX w.). Istoriczeskij oczerk. Grodno: 2010. (Ганчар, А.И. Римскокатолическая церковь в Беларуси (вт.пол. 19 - нач. 20 вв.). Исторический очерк. Гродно: 2010).

4. Janouskaja, W. W. Chryscijanskaja carkwa u Bietarusi 18631-11914 gg. Minsk: 2002. (Яноўская, В.В. Хрысціянская изарква у Беларусі у 1863-1914 г2. Мінск: 2002).

5. Katoliczeskaja cerkow nakanunie rewolucii $1917 \mathrm{~g}$. Sbornik dokumentow. Edited by M. Radwan. Lublin: 2003. (Радван, М. Католическая Церковь накануне революиии 1917 г. Сборник документов Сост. и отв. ред. Люблин: 2003)

6. Lukjanow, S. A., and A. G. Udidiw. "K woprosu o gosudarstwiennoprawowom regulirowanii dejatelnosti Rimsko-katokiczeskoj cerkwi w Rossii." In Gosudarstwiennaja stużba i kadry, no. 2 (2018). https://cyberleninka.ru/article/n/k-voprosu-o-gosudarstvenno-pravovom-regulirovaniideyatelnosti-rimsko-katolicheskoy-tserkvi-v-rossii. Accessed September 11, 2021 (Лукьянов С.А., Удодов А.Г. "К вопросу о государственно-правовом регулировании деятельности Римско-католической церкви в России.” In Государственная служба и кадры, №2. (2018).

7. Minenko, S. "W. Rossijskoje zakonodatelstwo po ochranie gospodstwujuszczej prawosławnoj wiery ot prozielitizma inowierczeskich cerkwiej (XVIII-XIX wieka)." In Juridiczeskaja nauka i praktika: wiestnik Niżegorodskij Akademii MWD. //https://cyberleninka.ru/article/n/rossiyskoe-zakonodatelstvo-po-ohrane-gospodstvuyuschey-pravoslavnoyvery-ot-prozelitizma-inovercheskih-tserkvey-xviii-xix-veka/viewer. Accessed: 10.06.2020. (Миненко, С.В. "Российское законодательство по охране господствующей православной веры от прозелитизма иноверческих церквей 
History of the Church
(XVIII-XIX века).” In Юридическая наука и практика: вестник Нижегородской академии МВД России.)

8. Popow, M. A. Mitropolit Stanistaw Bohusz Siestrencewicz (1731-1826 gg.): rol w formirowanii prawitelstwiennoj politiki k Rimsko-katoliczeskoj cerkwi na bietorusskich ziemlach (koniec XVIII - pierwaja czietwiert XIX w.). Minsk: 2012. (Попов, М.А. Митрополит Станислав Богуш-Сестренцевич (1731-1826 г2.): роль в формировании правительственной политики по отночению к Римско-католической иеркви на белорусских землях (конеи, XVIII - первая четверть ХІХ в.). Минск: 2012).

9. Valančius, M. Namu užrašai. Vilnius: Baltos lankos, 2003.

10. Zianiuk, R. U. "Baraćba z rymska-katalickomi bractwami jak forma abmieżawannia upływu kaścioła u druhoj pałowie XIX st." In Paustannie 1863-1864 gg. u Polszczy, Biełarusi, Litwie i Ukrainie: gistoryja $i$ pamiać. Zbornik nawukowych artykułau. 279-292. Minsk: 2014. (Зянюк, Р.У. “Барацьба з рымска-каталіцкімі брацтвамі як форма абмежавання ўплыву касцёла ў другой палове XIX стт.” In Паўстанне 1863 - 1864 г2. у Польшчь, Беларусі, Літве і Украіне: гісторыя і памящь : зб. навук. арт. Мінск: 2014, p. 279-292).

11. Zianiuk, R. U. "Kasacyja rymska-katalickich klasztarau u Mscisławie u XIX st." In Wiesnik Magiliouskaga dziarżaunaha uniwersiteta imia Kuliaszowa. Seryja A. Humanitarnyja nawuki 57, no. 1 (2021): 35-41. (Зянюк, P. У. “Касацыя рымска-каталіцкіх кляштараў у Мсціславе ў XIX ст.” In Веснік Магілёускага дзяржаўнага ўніверсітэта імя Куляшова. Серыя А. Гуманітарныя навукі 57, no. 1 (2021): 35-41)

12. Zianiuk, R. U. Nawuczalnuja ustanowy rymska-katalickaj carkwy u Bietarusi (1772 - 1914 gg.). Minsk: 2017. (Зянюк, Р.У. Навучальныя ўстановы рымска-каталіцкай изарквы у Беларусі (1772 - 1914 г2.). Мінск: 2017)

13. Zieniuk, R. W. "Organizacija, dejatelnost i sudby archiwow rimskokatoliczeskich monastyriej Biełarusi w konce XVIII - XIX wiekie." In Westnik Brianskogo gosudarstwennogo uniwersiteta 45, no. 3 (2020): 62-71. (Зенюк, Р.В. “Организация, деятельность и судьбы архивов римскокатолических монастырей Беларуси в конце XVIII - XIX веке.” In Вестник Брянского государственного университета 45, по. 3 (2020): 62-71. 